研 究 論 文

\title{
$50 \mathrm{kgf} / \mathrm{mm}^{2}$ 級球状黒鉛鋳鉄の電子ビーム溶接に関する研究*
}

\author{
一ポロシテイにおよばす溶接条件の影響—
}

\author{
柴田 文男**, 妿滕 粫一***, 藤崎登****
}

\author{
Study on the Electron Beam Welding of $50 \mathrm{kgf} / \mathrm{mm}^{2}$ \\ Class Nodular Cast Iron* \\ -Effect of Welding Conditions on Porosities-
}

by Fumio Shibata**, Seiichi Ando*** and Noboru Fujisaki****

This report describes the effect of welding conditions on porosities for electron beam welding of 50 $\mathrm{Kgf} / \mathrm{mm}^{2}$ class nodular cast iron $(6,12,18 \mathrm{~mm}$ thickness) with SUS304 (0.5 mm thickness) as insert metal.

The results obtained in this experimental investigation are summarized as follows; $5 \mathrm{hr}$ ).

(1) Amount of porosities of the fusion zone remarkably decreases by pretreatment annealing $\left(950^{\circ} \mathrm{C} \times\right.$

(2) For the range of $a_{b}$ value from 0.7 to 0.9 , well type beads are formed and no crack is observed.

(3) For the range of $a_{b}$ value more than unity, wedge type beads are formed and weld cracks occurred and porosities increased.

(4) Amount of porosities has tendency to decrease as beam current increase and to increase as welding speed increase.

(5) For base metal of 6,12 mm thickness, amount of porosities is remarkably decreased by 1 pass weld and for $18 \mathrm{~mm}$ thickness remarkably decreased by 2 passes weld.

(6) Under optimum welding conditions, sufficient strength of the welded joint can be obtained.

\section{1. 緒}

球状黑敛鋳鉄は懒鉄より強度と延性にすぐれており， 今日その普及は目覚しい発脿を遂げ，主に産業機械，自 動車部品，球状照敛鋳鉄管用として多方面に使用さ机て いる，しかしながら，球状黑鉊鋳鉄の溶接性に関する研 究報告は比較的少なく，雷子ビーム溶接においては，值 かに A. Matting らりが板厚 $6.12 \mathrm{~mm}$ の挦材に, 厚さ $1 \mathrm{~mm}$ の Ni をインサートメタルとして使用し, 溶接部 の諸性貵について報告しているにすぎない。したがっ

\footnotetext{
*原稿受付 昭和57年 1 月11日（昭和53年度春季全国大会にて発表）

**正 貝 日本大学理工学部 Member, College of Science and Technology, Nihon University

***正 員 日本大学生産工学部 Member, College of Industrial Technology, Nihon University

****正: 員 日本大学大学院 (現在東京消防庍) Member, Gradwate School of Nihon University (Present Address : Tokyo Fire Department)
}

て, 球状黑鉛鋳鉄の電子ビ一ム溶按については，まだ解 明しなりればならない問題点す多く, 特に溶接欠陷と溶 按条件との関連性については不明な点が多い。”、

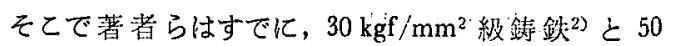

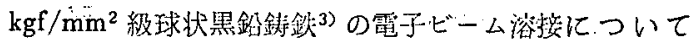
一速の奉験的研究を行ってきたが，その結果；檤揬球状 黑鉛鋳鉄を電子ビーム溶接する埸合；溶瀜凝固部に割れ や気孔か渚しく発生し，炎陷のない溶接部を得るととは 極めて困難であったが，I型突合せ面にインサートメタ ルを挿入するととと，適正溶接条件を選定するととに よって，溶接部の溶接欠楩を防止あるいは減少させ得る ことが明らかとなった。

本報告では, 板厚 $6,12,18 \mathrm{~mm}$ の $50 \mathrm{kgf} / \mathrm{mm}^{2}$ 級 球状黑鉛鋳鉄にオーステナイト系ステンレス鋼 SUS304 をインサートメタルとして使用し，電子ビーム浴接する 埸合について，且材の前処理焼鈍， $a_{b}$ 值( $)$ ，ビ一ム電 
流, 溶接速度, ビームパス回数などの溶接諸条件が, 溶 接部のポロシティおよび割れ, ビード外観, 溶融凝固部 の形状におよにすす影響について調査し, 特に本報では, ポロシティにおよぽす溶接条件の影饗について調べた。

さらに, 溶接部の機械的性質について若干検討を加え た.

\section{2. 実 験 方 法}

\section{1 供試材料および実験装置}

母材として使用した球状黒鉛鋳鉄 FCD 50 およびイ ンサートメタルとして使用したオーステナイト系ステン レス鋼 SUS 304 の化学組成之機珹的性質を Table 1 に 示す．母材の形状および寸法は， $6,12,18 \mathrm{t} \times 50 \times 70$ $\mathrm{mm}$ である. また, 母材はすべて機械加工の後, 鋳放し 材ならびに脱ガスとフェライト化 ${ }^{5}$ を目的にシリコニッ 卜電気邩により， $950^{\circ} \mathrm{C} \times 5 \mathrm{hr}$ の焼鈍を行ったあのを使 用した。

Table 1 Chemical compositions and mechanical properties of base metal and insert metal

\begin{tabular}{|c|c|c|c|c|c|c|c|c|c|c|c|c|c|}
\hline \multirow{2}{*}{\multicolumn{2}{|c|}{ Materials }} & \multicolumn{8}{|c|}{ Chemical composition $(\%)$} & \multicolumn{4}{|c|}{ Mechanical properties } \\
\hline & & \multirow{3}{*}{\begin{tabular}{|c|}
$c$ \\
3.40 \\
\end{tabular}} & \multirow{3}{*}{$\begin{array}{c}\mathrm{Si} \\
2.87\end{array}$} & \multirow{3}{*}{\begin{tabular}{|c|}
$n$ \\
0.35 \\
\end{tabular}} & \multirow{3}{*}{$\begin{array}{c}P \\
0.030\end{array}$} & \multirow{3}{*}{$\frac{5}{5}$} & \multirow{3}{*}{$\begin{array}{c}\mathrm{Ni} \\
-\end{array}$} & \multirow{3}{*}{$\frac{c_{r}}{c}$} & $0^{\circ 1}$ & \multicolumn{2}{|c|}{ 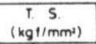 } & \multicolumn{2}{|c|}{$\begin{array}{l}\text { E. L. }(\%) \\
\text { GL. } 30(\mathrm{~mm})\end{array}$} \\
\hline \multirow{2}{*}{$\begin{array}{l}\text { Base } \\
\text { metal }\end{array}$} & \multirow{2}{*}{$\begin{array}{l}\text { Nodular } \\
\text { Cast iron } \\
\text { (FCD } 50)\end{array}$} & & & & & & & & 00018 A & $\Delta C$ & 59.6 & $A C$ & 12.5 \\
\hline & & & & & & & & & 00010 A & $\mathrm{AN}$ & 49.3 & $A N$ & 15.1 \\
\hline $\begin{array}{l}\text { Insert } \\
\text { metal }\end{array}$ & 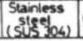 & 0.07 & 0.68 & 0.97 & 0022 & 0.12 & 8.64 & $18.43 \mathrm{~F}$ & bookd & & 3 & & 60 \\
\hline & & & & & & & & & & & & & \\
\hline
\end{tabular}

インサートメタルの形状および寸法は， $0.5 \mathrm{t} \times 6,12$ ， $18 \times 70 \mathrm{~mm}$ とし, Fig. 1 に示すでとく, I 型突合せ面に 合致させ突合せ溶接を行った。なお，母材は溶接直前に 脱磁を行い, 母材の突合せ面とインサートメタルは，ア セトンで泒浄し十分に脱脂を行った。

溶接装置は, 最大加速電圧 $150 \mathrm{kV}$, 最大出力 $6 \mathrm{~kW}$, 最大ビーム電流 $40 \mathrm{~mA}$ の高電圧高真空型電子ビーム溶 接装置を使用した。なお，本実験では，加速電圧 $150 \mathrm{kV}$, 加工距離 $150 \mathrm{~mm}$, 真空度 $1 \times 10^{-4} \mathrm{~T}$ orr を一定として 実験を行い, 主に溶接条件を種々変えた場合の溶接部縱 断面に占めるポロシティの発生率を Fig. 2 より求めた.

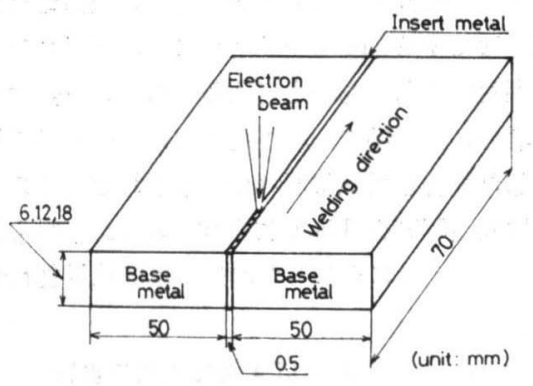

Fig. 1 Joint configuration with insert metal

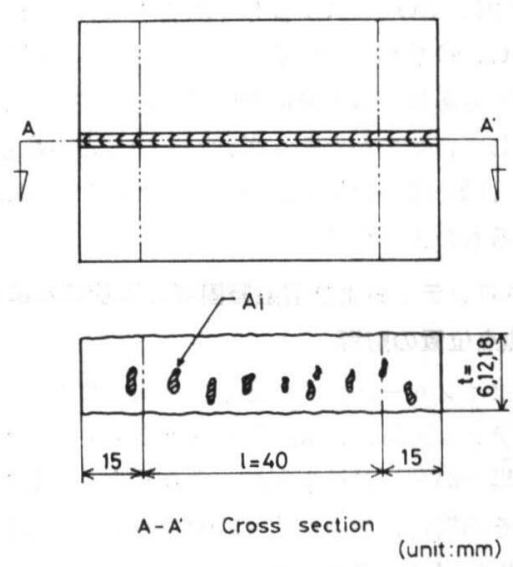

Relative porosity $=\frac{\Sigma A_{1}}{1 \times t} \times 100(\%)$

Fig. 2 Evaluation of porosity

\section{3. 実験結果および検討}

\section{1 ポロシティにおよぼす前処理焼鈍の影響}

母材中におけるガスの放出の促進ならびにフェライト 化を目的として, 溶接前の母材に $950 \mathrm{C} \times 5 \mathrm{hr}$ の前処理 焼鈍を行った。

Fig. 3 は板厚 $12 \mathrm{~mm}$ の母材に鋳放し材を使用した場 合と， $950 \mathrm{C} \times 5 \mathrm{hr}$ の焼鈍材を使用した場合のビード縦 断面のマクロ組織とポロシティの発生率を示したもので ある. ポロシティは鋳放し材の場合, ルート部から中央 部において，2.92\%発生したのに対し，焼鈍材の場合は ルート部に発生し, ポロシティは1.22\%に隇少してい る.

しかし,一般にリムド鋼の電子ビーム溶接において

\begin{tabular}{|c|c|c|}
\hline $\begin{array}{l}\text { Heat } \\
\text { treatment }\end{array}$ & Longitudinal cross section & $\begin{array}{c}\text { Relative } \\
\text { porosity }\end{array}$ \\
\hline As-cast & $1 \%$ & 2.92 \\
\hline $\begin{array}{c}\text { Annealed } \\
950^{\circ} \mathrm{C} \times 5 \mathrm{hr}\end{array}$ & & 1.22 \\
\hline
\end{tabular}

Fig. 3 Longitudinal cross section at different heat treatment

Notes: 1) $a_{b}$ parameter: 0.8

2) Beam current: $18 \mathrm{~mA}$

3) Welding speed: $600 \mathrm{~mm} / \mathrm{min}$

4) FCD $50,12 \mathrm{mmt}$ 
は, 溶接中に CO ガスが著しく増加するとの報告6)や 母材中の $\mathrm{C}, \mathrm{O}$ 量が増加するとブローホールが增加する との報告7〕あり, 本実験においても, ポロシティ発生 の因子として，ガスが大きく影響していると考えられ， 焼鈍による母材中の $\mathrm{O}$ 量の低下 ${ }^{8)}$ が，ポロシティを隇少 させているあのと考える。

\section{2 ポロシティおよひ溶融疑固部の形状におよぼす 焦点位置の影響}

Fig. 4 はインサートメタルとして使用したオーステナ イト系ステンレス鋼に， $a_{b}$ 值を種々変えてビード溶接 を行った場合のビード横断面のマクロ写真を示したもの である．その場合，溶接入熱 $(2700 \mathrm{~J} / \mathrm{cm})$ を一定とし， $\mathrm{a}_{\mathrm{b}}$ 值を 0.6 1.6まで種々変化させて溶接を行い, 溶融 凝固部の形状におよぼす影響について検討した，その結 果, $a_{b}$ 值 $0.6 \sim 0.9$ 亿おいては溶込み深さは $a_{b}$ 值の増 加にとあない増大し, $\mathrm{a}_{\mathrm{b}}$ 值1.0〜1.6においては, 逆に 溶込み深さは減少する傾向を示した，その場合の溶融凝 固部の形状は, $a_{b}$ 值 $0.5,0.6$ および1. $0,1.1,1.2$ の場 合, クサビ型ビードを形成し, $a_{b}$ 值 $0.7 \sim 0.9$ では, ほ ぼ安定な井戸型ビードを形成した．また， $\mathrm{a}_{\mathrm{b}}$ 值の增加 に伴い, クサビ型ビード, 井戸型ビード, クサビ型ビー ド，ワインカップ型ビードへと移行する形状が観察され た。なお，溶込み深さの増大する $\mathrm{a}_{\mathrm{b}}$ 值 $0.8,0.9$ は, ビードが貫通し表面ビード幅は極めて狭く, 滑らかで良 好なビード外観が得られている。

\section{ab parameter}

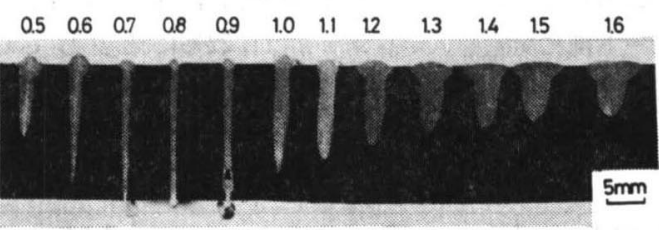

Fig. 4 Effect of $a_{b}$ parameter on transverse profile section

Notes: 1) Beam current: $18 \mathrm{~mA}$

2) Welding speed: $600 \mathrm{~mm} / \mathrm{min}$

3) Insert metal: Stainless steel

Fig. 5 は板厚 $6.12 \mathrm{~mm}$ の母材に, インサートメタル を挿入して，それぞれ溶接入熱 $(1000 \mathrm{~J} / \mathrm{cm}, 3300 \mathrm{~J} / \mathrm{cm})$ を一定として， $a_{b}$ 値を種々変えて溶接した場合のポロ シティの発生率を示したあのである，ポロシティは板厚 $6,12 \mathrm{~mm}$ の母材とむ $\mathrm{a}_{\mathrm{b}}$ 值 0.8 で減少しているが, 板 厚 $6 \mathrm{~mm}$ の母材では, ポロシティにおよぽす各 $\mathrm{a}_{\mathrm{b}}$ 值 の影響はあまり認められなかった。一方, 板厚 $12 \mathrm{~mm}$ の母材では, $a_{\mathbf{b}}$ 值 0.9 の場合, 溶込み深さが増大し, 一部溶落ちが認められ, そのためルート部に Rポロシ

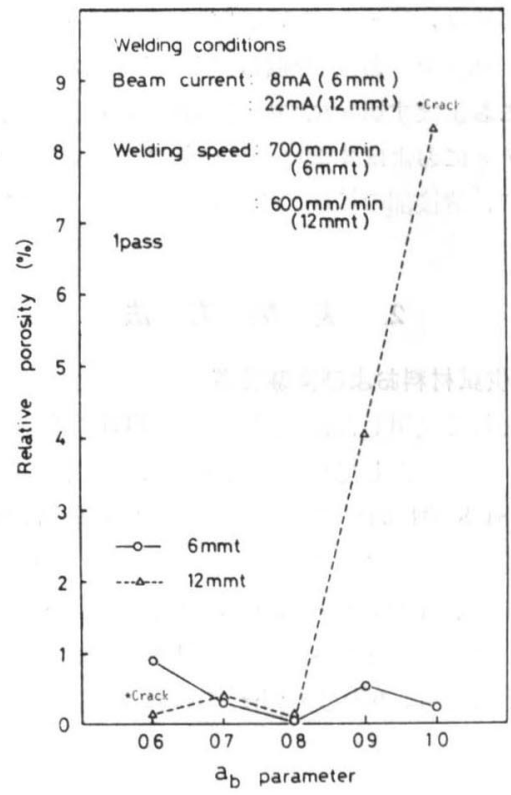

Fig. 5 Effect of $a_{b}$ parameter on relative porosity

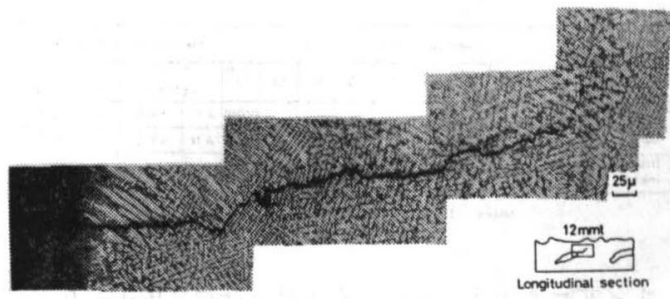

Fig. 6 Transverse crack of weld zone Notes: 1) $a_{b}$ parameter: 1.0

2) Beam current: $22 \mathrm{~mA}$

3) Welding speed: $600 \mathrm{~mm} / \mathrm{min}$

ティが発生したものと思われる。なお，溥板の場合に は, 各 $\mathrm{a}_{\mathrm{b}}$ 值に対して, 溶融凝固部の形状に差異を生じ ないが, 板厚 $12 \mathrm{~mm}$ の母材では, 各 $\mathrm{a}_{\mathrm{b}}$ 值に対して, 溶融疑固部の形状に著しい影響をおよはしている。した がって, ポロシティの発生原因の一つとして, 溶融疑固 部の形状すなわち $\mathrm{a}_{\mathrm{b}}$ 值の設定条件に大きく依存し, 井 戸型ビードを形成する $\mathrm{ab}_{\mathrm{b}}$ 值を採用し, 極力母材側の溶 融を最少限にする $a_{b}$ 值を設定しなければポロシティの 減少は期待できないあのと考える。なお， $a_{b}$ 值 0.6 , 1.0 の場合, 溶接部に割れが発生し, 直接球状黒鉛鋳鉄 を溶接した場合と同様な割れが観察された。 その場合の 割れの顕微鏡写真を Fig. 6 亿示す. 写真から明らかなよ うに，ポロシティに連なった粒内および粒界割れが認め られた。

\section{3 ポロシティにおよぼす溶接入熱の影響}

Fig. 7 は板厚 $12 \mathrm{~mm}$ の母材に, ビーム電流を種々変 


\begin{tabular}{|c|c|c|c|}
\hline $\begin{array}{l}\text { Beam } \\
\text { current }\end{array}$ & Top bead & Bottom bead & $\begin{array}{l}\text { Cross } \\
\text { section }\end{array}$ \\
\hline $16 \mathrm{~mA}$ & & & \\
\hline $18 \mathrm{~mA}$ & & & \\
\hline $20 \mathrm{~mA}$ & & & \\
\hline $22 \mathrm{~mA}$ & & & \\
\hline $24 \mathrm{~mA}$ & rescerrest & 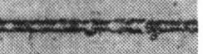 & \\
\hline $26 \mathrm{~mA}$ & 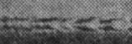 & 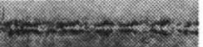 & \\
\hline
\end{tabular}

Fig. 7 Bead appearance and cross section in various beam current

Notes: 1) $a_{b}$ parameter: 0.8

2) Welding speed: $600 \mathrm{~mm} / \mathrm{min}$

3) FCD 50, $12 \mathrm{mmt}$

えて溶接を行った場合の表面および㐮波ビード外観と， 溶融疑固部の形状を示したあのである。ビーム電流が 22 26 mA の場合, 表面および裹波ビード外観が良好な 溶接が得られている. また, 溶融凝固部の形状は, ビー 么電流が 22 26 mA においては, ほほ一定な井戸型 ビードを形成している。しかしながら, ビーム電流が $16 \mathrm{~mA}$ の場合, 表面ビード幅より裹波ビード幅が狭く, 一定な溶融凝固部の形状は得られていない. Fig. 8 はそ の場合のビード縦断面のマクロ写真とポロシティの発生 率を示したあのである.ビード外観が良好な $22 \sim 26 \mathrm{~mA}$ の範囲では, ポロシティは著しく隇少している.また, ポロシティはビーム電流の増加に伴って, ボイド状の $\mathrm{R}$ ポロシティから微細な A ポロシティに移行する形状が認 められた.

Fig. 9 は板厚 $6,12,18 \mathrm{~mm}$ の母材に, ビーム電流を 種々変えて溶接を行った場合のポロシティの発生率を示 したあのである. 四から明らかなように，板厚 $6 \mathrm{~mm}$ の 母材では, ビーム電流が 6 12 mA の範囲では, ポロシ ティの発生は少なくビーム電流の影響は認められない. しかし, 板厚 $12 \mathrm{~mm}$ の母材では, ビーム電流の増加に とあない，ポロシティは顕著に減少するととが認められ た。なお, 板厚 $18 \mathrm{~mm}$ の場合は, 板厚 $12 \mathrm{~mm}$ ほどポロ シティの減少は著しくなかった，また，各板厚における
溶接入熱は, 板厚 $6 \mathrm{~mm}$ の場合 $(900 \sim 1800 \mathrm{~J} / \mathrm{cm})$, 板 厚 $12 \mathrm{~mm}(2400 \sim 3900 \mathrm{~J} / \mathrm{cm})$, 板厚 $18 \mathrm{~mm}(3600 \sim$ $4800 \mathrm{~J} / \mathrm{cm}$ ) である.

\begin{tabular}{|c|c|c|}
\hline $\begin{array}{l}\text { Beam } \\
\text { current }\end{array}$ & Longitudinal cross section & $\begin{array}{l}\text { Relative } \\
\text { porosity }\end{array}$ \\
\hline $16 \mathrm{~mA}$ & & $\begin{array}{l}8.91 \\
(\%)\end{array}$ \\
\hline $18 \mathrm{~mA}$ & & $\frac{1.22}{(\%)}$ \\
\hline $20 \mathrm{~mA}$ & & $\begin{array}{l}0.44 \\
(\%)\end{array}$ \\
\hline $22 \mathrm{~mA}$ & & $\begin{array}{l}0.05 \\
(\%)\end{array}$ \\
\hline $24 \mathrm{~mA}$ & & $\begin{array}{l}0.01 \\
(\%)\end{array}$ \\
\hline $26 \mathrm{~mA}$ & & $\begin{array}{l}0.04 \\
(\%)\end{array}$ \\
\hline
\end{tabular}

Fig. 8 Longitudinal cross section of weld zone in various beam current

Notes: 1) $\mathrm{a}_{\mathrm{b}}$ parameter: 0.8

2) Welding speed: $600 \mathrm{~mm} / \mathrm{min}$ 3) FCD $50,12 \mathrm{mmt}$

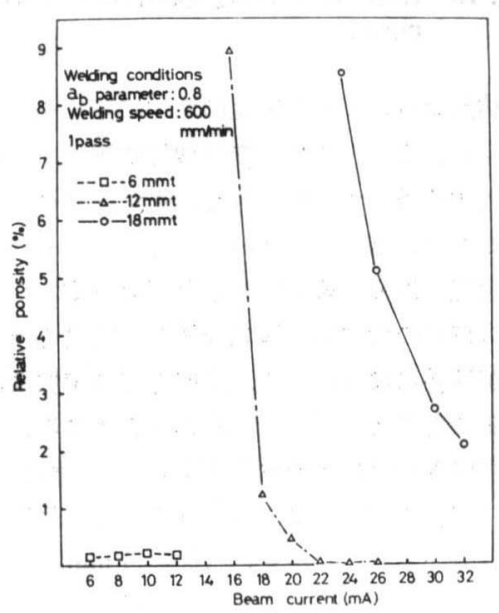

Fig. 9 Effect of beam current on relative porosity 
次に Fig. 10 は前述の場合之同様な板厚について，ポ ロシティにおよぼす溶接速度の影響を示したすのであ る. その結果, ポロシティは板厚 $6 \mathrm{~mm}$ の母材では, すへてて球状のAポロシティが若干発生し, 高速 $(800 \mathrm{~mm} /$ $\min$ ）で若干ポロシティの増大が認められた。また，板 厚 $12,18 \mathrm{~mm}$ の場合は, 溶接速度の増加により, ポロ シティおよびボイド状の久陥が著しく発生し, 板厚 12 $\mathrm{mm}$ より $18 \mathrm{~mm}$ の方が, ポロシティの発生が著しかっ た, なお, 板厚 $18 \mathrm{~mm}$ の母材で, 溶接速度 $800 \mathrm{~mm} /$ $\min$ の場合に溶込み不足を生じ，そのためポロシティは わずかに減少したあのと思われる，溶接入熱は，板厚 6 $\mathrm{mm}$ の場合 $(1800 \sim 900 \mathrm{~J} / \mathrm{cm})$, 板厚 $12 \mathrm{~mm} \mathrm{(4050}$ $2025 \mathrm{~J} / \mathrm{cm})$, 板厚 $18 \mathrm{~mm}(5400 \sim 2700 \mathrm{~J} / \mathrm{cm})$ である.

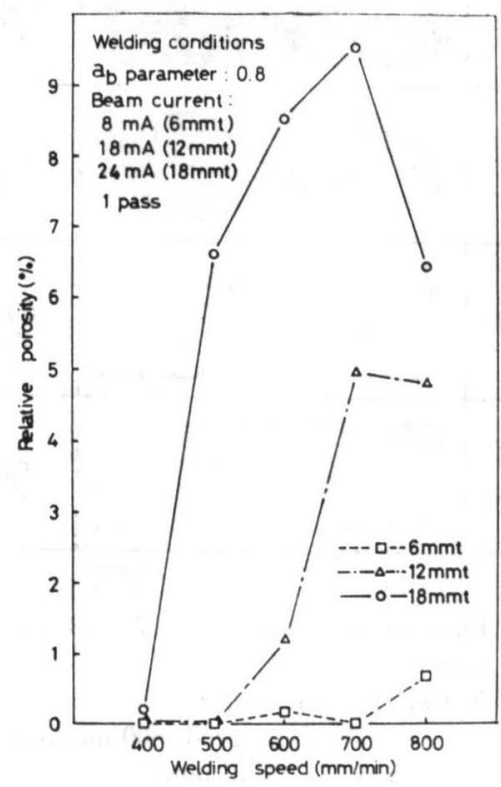

Fig. 10 Effect of welding speed on relative porosity

以上の結果より, ビーム電流の増加に伴ってポロシ ティは減少し, また, 溶接速度の増加に伴ってポロシ ティは増大する傾向が認められた。 また，母材の板厚が 厚くなるに従い, ポロシティ発生に対し, ビーム電流お よび溶接速度の影響が著しいととが認められた。従っ て, ビーム電流の増加は, 溶融凝固部の凝固を遅延しガ スの放出が容易になり, 一方, 溶接速度の増加は, 凝固 を速くするととによりガスの脱出が困難になり, ポロシ ティの発生に著しい影響をおよぼすすのと考える。ま た, 板厚の増加については, 本実験の場合井戸型ビート゚ を形成する条件下で, しかむ, 溶融幅(1 mm 以下)が極 めて狭く, 溶接時に発生するガスが板厚の増加ととむに 増大し, ポロシティの発生を大きくした一因と考える.

\section{4 ポロシティにおよぼすビームパス回数の影葃}

板厚 $6,12 \mathrm{~mm}$ の母材では, 適正な溶接条件を選定す ることにより，1 パスで良好なビード外観とポロシティ の極めて少ない溶接部が得られることを明らかにした. しかし, 板厚 $18 \mathrm{~mm}$ の母材では 1 パス溶接において, 低速時にポロシティは著しく減少する傾向を示したが， ビード表面にアンダーフィルが垫められ，良好なビード 外観は得られなかった，そこで，良好なビード外観を得 るととあにポロシティを減少させるために，Fig.11 に 示すどとく, ビームパス回数の影響を検討した. ポロシ ティは, 1 パス溶接の場合は $2.71 \%$ 発生し, 2 パス溶接 の場合は $0.63 \%$ に減少することが認められた。また， 1 パスおよび 2 パス溶接とも，良好なビード外観が得られ ている.なお, 溶接部のポロシティ減少に対し，1 パス 溶接の場合は, 溶接速度を遅くすることによって, 凝固 を遅延させ，ポロシティは滅少することが考えられる。 一方， 2 パス溶接の場合は，1 パス溶接で溶接部に残留 したガスをさらに溶接するととによって，ガスの放出を 促進し, その結果, ポロシティは減少したあのと考える.

また，ポロシティは，1 1゚ス溶接の場合は溶融凝固部 のルート部に発生し， 2 パス溶接では溶融凝固部の中央 部から上部に分散する傾向が認められ，板厚が厚くなる に衒い，2 パス溶接はポロシティ減少に有効であるよう に思われる。

\section{5 溶接部のミクロ組織および硬さ分布}

Fig. 12 は溶接部近傍のミクロ組織と硬さの関係を示 したあのである. 溶融凝固部は硬さが低く，オーステナ イトでセルデンドライト組織を呈している，また，ボン ド部の黑鉛の周囲は極めて硬化し, 共晶およびマルテン

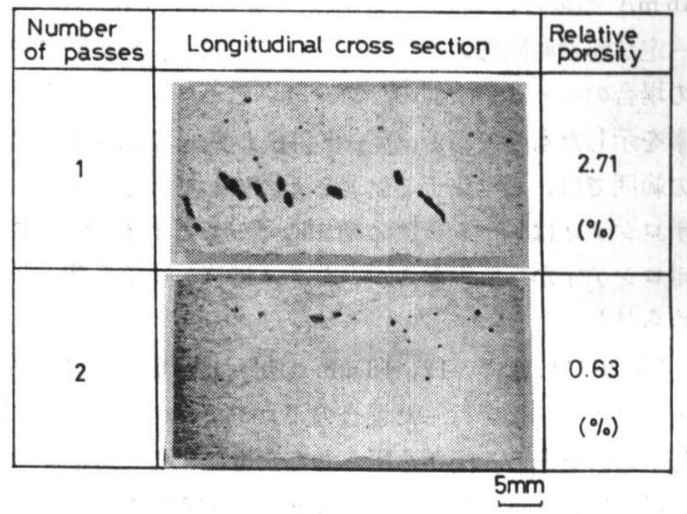

Fig. 11 Longitudinal cross section of weld zone in various passes

Notes: 1) $a_{b}$ parameter: 0.8

2) Beam current: $30 \mathrm{~mA}$

3) Welding speed: $600 \mathrm{~mm} / \mathrm{min}$

4) FCD 50, $18 \mathrm{mmt}$ 


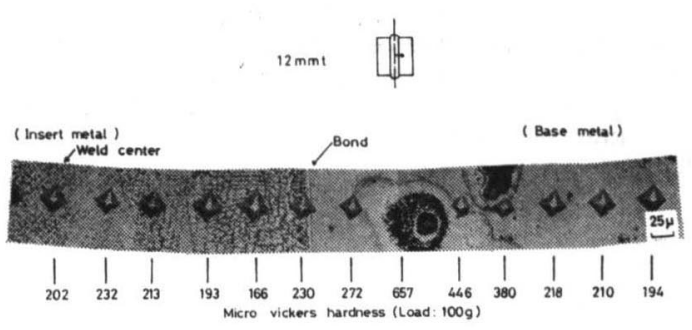

Fig. 12 Microstructure and micro-vickers hardness of weld zone

Notes: 1) $a_{b}$ parameter: 0.8

2) Beam current: $22 \mathrm{~mA}$

3) Welding speed: $600 \mathrm{~mm} / \mathrm{min}$

サイトの生成が認められる。

Fig. 13 は $\mathrm{a}_{\mathrm{b}}$ 值 $0.6,0.8,1.0$ の場合の溶接部の硬 さ分布を示したものである， $a_{b}$ 值 $0.6,1.0$ の場 合, $a_{b}$ 值 0.8 と比較して溶融凝固部の幅は広範囲で硬化し ているととがわかる。しかし, 溶融凝固部の幅が拡大す る $\mathrm{a}_{\mathrm{b}}$ 值 0.6 および 1.0 の場合は, クサビ型ビードを形 成し, そのため母材の黒鉛が多く溶融して, 溶融凝固部 が硬化したために，割れが発生したたのと考える。な お, 溶接部の治金的な問題については, 別途検討を行っ ている.

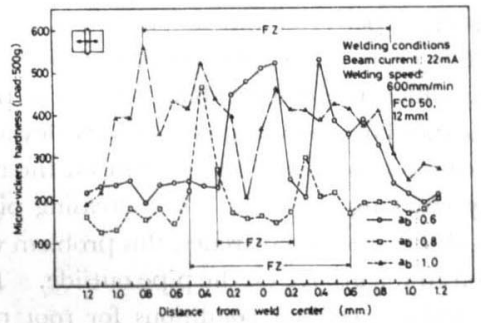

Fig. 13 Effect of $a_{b}$ parameter on micro-vickers hardness distribution of weld zone

\section{6 溶接部の継手引張試験}

Table 2 に示すごとく, $a_{b}$ 值 0.8 8 よ゙1.0の継手に

Table 2 Tension test

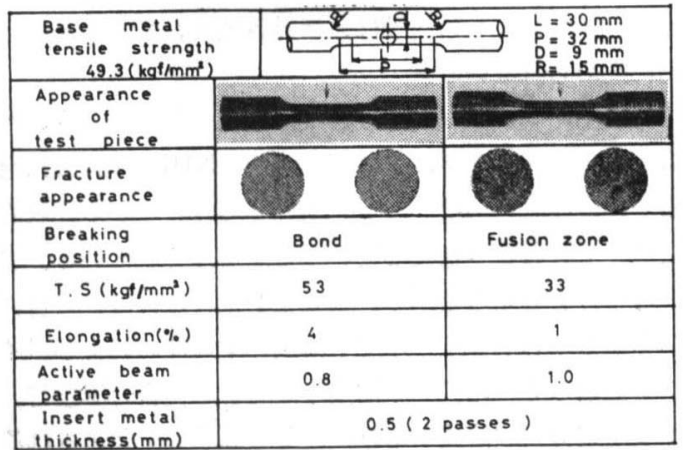

ついて, JIS 4 号試験片に準じて, 継手引張試験を行っ た結果， $a_{b}$ 值 0.8 の場合は, ボンド部で破断しており, 十分な強度を有する継手が得られているととがわかる。

\section{4. 結}

本報告においては, 板厚 $6,12,18 \mathrm{~mm}$ の $50 \mathrm{kgf} /$ $\mathrm{mm}^{2}$ 級球状黒鉛鋳鉄に SUS 304 ステンレス鋼をイン サートメタルとして使用し, 電子ビーム溶接を行う場合 について, 主としてポロシティにおよほすす溶接条件の影 㗽を検討してきた。 その結果, 次の結論が得られた。

(1) 板厚 $6,12,18 \mathrm{~mm}$ の母材に $950^{\circ} \mathrm{C} \times 5 \mathrm{hr}$ の前 処理焼鈍をして溶接を行った場合, ポロシティは顕著に 減少する. また, 母材の板厚が厚くなるに従い, 前処理 焼鈍によるポロシティの減少は顕著である。

(2) 板厚 $6,12,13 \mathrm{~mm}$ の母材と屯 $\mathrm{a}_{\mathrm{b}}$ 值 $0.7 \sim 0.9$ の場合, 良好なビード外観が得られた。 また, 溶融凝固 部の形状む一定な井戸型ビードを形成した。なお, 溶融 凝固部の形状がクサビ型ビードを形成する $\mathrm{a}_{\mathrm{b}}$ 值 0.6 , 1.0 の場合, 溶融凝固部に顕著な割れとポロシティが発 生する。

(3) ポロシティはビーム電流の増加に伴って減少し, 一力, 溶接速度の増加に伴って, ポロシティは増大する 傾向が諗められる。 また, ポロシティの発生に対し, 母: 材の板厚が厚くなるに従い，ピーム電流および溶接速度 の影響が顕著である。

(4) 板厚 $6,12 \mathrm{~mm}$ の母材では, 1 パス溶接でポロ シティは著しく減少する傾向を示したが, 板厚 $18 \mathrm{~mm}$ の母忉では，2 パス溶接の場合ポロシティは顕著に減少 する.

（5）適正な溶接条件で溶接を行った場合，継手効率良 好で健全な溶接部を得るととが可能である。

\section{謝辞}

本研究において, 種々御援助いただいた盰団法人日本 溶接技術センターの関係各位ならびに熱心に実験に協力 していただいた日本大学生産工学部機械工学科溶接研究 宾の卒業研究生の諸君に感謝の意を表わします.

\section{参考 文 献}

1) A. Matting und K. Seifert; Erfahrungen beim Elektronenstrahlschweißen von Gußeisen mit Kugelgrafit, Schwei jen und Schneiden, 20-6 (1968), 266-269

2）安藤, 朝比奈, 平野; 传鉄の電子ピーム溶接に関する二, 三の実騙, 溶接学会全国大会講溦概要，第14集（1974），144-145，第12回電子 ピーム溶接研究委員会資料, EBW-97-73 (1974)

3）安藤, 柴田, 藤崎; 球状黑鉛铸鉄の電子ビーム溶 接（第 2 報）、第 26回日本溶接協会特殊材料溶接研究委員会铸物小委員会資料. CW $-51-78$ (1979)

4) Y. Arata; Terms and Definitions Proposed from Japan, IIW, (1972)

5）大和田㖶, 西村, 宮田；球状黑鉛鋳鉄のフェライト化速度につい 
خ. 鋳物, 44-8 (1972), 666-673

6) M. J. Bibby, G. Burbidge and J.A. Goldak; Gases Evolved from Electron Beam Welds in Plain Carbon Steels, Weld. J. 51-12 (1972), 844-847

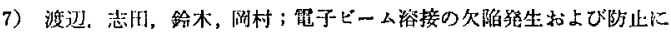

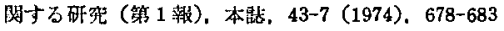

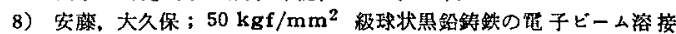

(主として溶接部の組織䘽察)，溶接学全全国大会满演梘要，第 26 策 (1980)，294-295，第 31 回電枯ビーム溶接研究委員会资料 EBW-240-80(1980)

\title{
配管の高速自動溶接に関する研究 (第1報)*
}

\author{
一溶'接 施 工一
}

常富 栄一**, 馬田 豊昭**, 斎藤袈装雄**, 棌井 英夫**, 斉藤 逯郎 ${ }^{* * *}$

\author{
Study on High Speed Automatic Welding of Piping (Report 1)* \\ -Welding Procedure-
}

by Eiichi Tsunetomi**, Toyoaki Bada** Kesao Saito**, Hideo Sakurai** and Tatsuro Saito***

Pipeline installation requires the use of a welding method presenting high pipe-laying efficiency and therefore high welding speed.

The present report describes the development of welding procedure by the automatic one side downhill welding method using high-current-density GMAW with regard to the girth welding of pipe. In this method, the groove root is made tight and non-gapped, and welding is performed in the narrow gap with little deposit metal, in order to shorten the pipe alignment and welding time. An appropriate procedure for this method was established by developing the downhill welding which uses copper backing on the pipe inside and small diameter solid wire on the pipe outside. When the standard welding conditions are deviated from, the welding arc will touch the copper backing sometimes causing the copper to deposit on the root bead. This deposition of copper on root beads causes not only cracking of beads, but decreasing pipelaying efficiency due to consumption of copper backing. As a result of various researches, this problem was resolved by preparing another groove on the pipe inside in addition to the groove on the pipe outside. The use of the improved shape of groove expanded the zone of appropriate welding conditions for root pass toward the high-speed welding side. The built-up sequence was divided basically into three kinds of passes, the root pass, intermediate pass and cap pass, and each pass was expressed graphically to facilitate the selection of welding conditions for assuring no welding defects and high welding efficiency.

This welding method was applied into a welding system with the development in computor control technique and with the development in internal clamp.

\section{1. 緒}

\section{言}

近年, 溶接自動化の傾向はエレクトロニクス技術の発 展普及と共にあらゆる分野におよび，スポット溶接をは じめアーク溶接もロボット化する時代に入ろうとしてい る.しかし.リリルタイム:フィードバック機能を備え た人て知能型アーク溶接機の完成期には至っていない。

\footnotetext{
＂*原稿受付，昭和57年 2 月12日（昭和54年度秋季全国大会にて登表）

**正員 新日本製鉄(株) 製品技衍研究所 Member, Nippon Steel Co. Products Research \& Development Lab.

***正員 新日本製鉄(株)相模技街センター Member, Nippon Steel Co. Sagamihara Engineering Center
}

一方, 海底エネルドー凟源の開発に久くととができない 海底パイプラインの建設は，世界各地で，ますます積極 的に進められている。

海底パイプラインの敷設作業は僌設船上に配置された 複数の作業ステージにおいて，溶接，NDI，叙覆装に至 る一連のパイプ接続作業を, 連続して行いながら間歇的 にパイプを海底へ敷設していく方法が採られている。膨 大な経費を要する船団の稼動効果を上げるには，接合作 業を速めるしかなく，中で屯溶接作業速度の向上がポイ ントとなっている．ての溶接は固定管の突合せ溶接で， かつ全姿勢裹波溶接であり，しかあ高品質を要求される 